Diyala Journal

ISSN 1999-8716

of Engineering

Printed in Iraq

Sciences

Vol. 06, No. 02, pp. 38-56, June 2013

\title{
DESIGN AND SIMULATION OF HYBRID SYSTEM FOR ELECTRICITY GENERATION IN IRAQI RURAL REGIONS
}

\author{
Qusay Abdul-Jabbar Jawad ${ }^{1}$, Kareem Kadhum Gasem ${ }^{2}$, Mohammed Ridha Jawad ${ }^{3}$ \\ ${ }^{1,2}$ Energy and Renewable Energies Technology Center, University of Technology, \\ ${ }^{3}$ Engineering College, Diyala University \\ E-mail: Krem1957@yahoo.com ${ }^{1}$, qaj_2010@yahoo.com², \\ mohammed_altimmim@yahoo.com ${ }^{3}$ \\ (Received:21/11/2011; Accepted:2/9/2012)
}

\begin{abstract}
In this research the design and simulation of a hybrid wind-solar and diesel was studied and discussed to be used in the far areas of our country to help the people there in improving their life where electricity from the main grid has not reached yet.

The proposed connecting configurations are compared to select the one with the best efficiency of power consumption to the consumers by considering each power sources independently. It is found that best efficiency of power consumption can be achieved with the Mixed-coupling HPSs, when compared with the other topologies and the selected topology is used for further investigation.
\end{abstract}

Keyword: Solar cells, Electricity generation, Renewable energy.

\section{INTRODUCTION}

Remote rural areas, especially in IRAQ, are in great need of affordable and reliable electricity to achieve development. Likewise, an overview through the most important literature on rural electrification proves that renewable energies are one of the most suitable and environmentally friendly solutions to provide electricity within rural areas.

Some of the advantages of using renewable energies are ${ }^{(3)}$ :

- Gain an immediate access to reliable electricity at any time.

- Avoid long waits for grid extension and permit the connection it comes.

- Reduce the dependency from oil price fluctuations.

- Reduce the transportation costs of fuels.

- Improve health care and reduction in rural areas.

- Increase economic productivity and create local employment opportunities. 
- Fight climate change and poverty.

- Allow for a better use of local natural resources.

\subsection{System components}

The hybrid power system, described here, basically includes the following main elements:

1. Renewable energy sources: PV-system, Wind generator.

2. Energy storage bank: Battery bank.

3. Backup energy source: Diesel generator set.

4. AC-loads.

5. Power electronic devices.

\subsubsection{Diesel Generator set}

A diesel generator is a diesel engine combined with an electrical generator (alternator) via a rotating part to generate electric energy. The diesel engine coverts the chemical energy available in fuel into mechanical energy in which the produced mechanical power rotates the engine shaft connected to the alternator.

This generator-set has the following drawbacks:

- Very heavy and difficult to handle.

- Noisy.

- Low efficiency.

\subsubsection{PV-array system}

The solar irradiation varies daily with time and seasonally. These in turn results to the reliability problems from such sources of energy seeking energy conversion, energy storage and load control etc. when compared with conventional sources of energy.

\section{Advantages}

- Environmentally friendly and pollution free (emission free).

- No use of fuels and water.

- Requires minimum maintenance and low running cost.

- Long lifetime, up to 30 years.

- Modular or "custom made" energy, can be designed for any applications from watch to a multi-megawatt power plant. 
- No restriction on harvesting as far as there is light.

\section{Drawbacks}

- High initial cost.

- PV can't operate without light.

- PV generates DC current: energy storage, like batteries, and inverters are needed.

- Large area needed for large scale applications.

- Cannot always generate stable output with ever-changing weather conditions.

Fig.(1) shows PV-array system, which is a part of the whole system, with battery bank charging or supplying the AC load.

The number of series connected PV-modules can be calculated as follows ${ }^{(12)}$ :

$N_{s}=V_{s y s} / V_{\text {mod }}$

Where,

$N_{s}=$ the number of series connected PV-module (rounded up to a whole number).

$V_{\text {sys }}=$ nominal system voltage.

$V_{\text {mod }}=$ nominal module voltage .

The number of parallel panels can be determined as ${ }^{[9,12]}$ :

$N_{p}=L_{D A}(A: L) /(1-S L) I_{m p} D S H$

Where,

$N p=$ number of parallel connected modules (rounded up to a whole number)

$L_{D A}=$ Average daily load $(\mathrm{A})$

$A: L=$ average photovoltaic Ah available-to-average daily load Ah ratio

$S L=$ system loss

$I_{m p}=$ module current at maximum power (A)

$D S H=$ the daily sun hours

The average daily PV-to-load Ah ratio can be determined from ${ }^{(12)}$

$A: L=I_{\text {array }} D S H / I_{\text {load }} D R T$

Where,

DRT is the daily running time of the system and typical $A: L$ values are (1.1-1.2) for non-critical loads and (1.3-1.4) or higher for critical loads, and the month with lowest $A: L$ ratio has to be taken when designing a PV-array system ${ }^{[12]}$.

The total number of PV-modules forming PV-array is, therefore ${ }^{(13)}$ :

$N_{\text {mod }}=N_{p} / N_{s}$ 


\subsubsection{Wind Turbines}

Wind turbines are used to generate electricity from kinetic power of the wind i.e. the generation of wind energy primarily depends on the wind speed ${ }^{[21]}$. Modern wind turbines capture more than $90 \%$ of available energy from wind, compared with fuel efficiency between $30-40 \%$ for a conventional coal fired station, which typically loses a significant portion of energy through heat loss and pollution.

Some advantages of using wind turbines to generate power are:

- environmentally friendly

- produce no pollution

- no traditional fuel required

- requires relatively little maintenance

- long life time (up to 30 years)

\section{Disadvantages}

- interference with radio/TV signals if located inappropriately

- the wind doesn't blow all the time at required speed

- high initial cost

$p=\frac{1}{2} \rho A_{r o t} v^{3}(\mathrm{w})$

Where:

$P$ : mechanical power in moving air (watts).

$\rho:$ air density $\left(\mathrm{kg} / \mathrm{m}^{3}\right)$.

$\mathrm{A}_{\text {rot }}=$ area swept by the rotor blades exposed to the wind $\left(\mathrm{m}^{2}\right)$.

$v=$ wind speed $(\mathrm{m} / \mathrm{sec})$.

\subsection{Technical configurations for hybrid power systems}

The hybrid system can be designed following different configurations to effectively use the locally available renewable energy sources and to serve all power appliances.

\subsubsection{AC/DC-coupled Hybrid Power Systems}

For the hybrid power system whose demand is to be supplied from wind turbine, PVsystem, a diesel generator and a battery, different configurations are explained in ${ }^{(1,3,5,21)}$. In general, there are three accepted categories hybrid system technological configurations according to the voltage they are coupled with each other and the load. These are:

a) AC-coupled hybrid power systems. 

b) DC-coupled hybrid power systems.
c) Mixed-coupled hybrid power systems.

\subsubsection{AC-coupled Hybrid power Systems}

With this type of configuration, the different HPSs are connected at the AC-bus with the load. The AC coupled HPSs are further divided into two sub-topologies.
i. $\quad$ Centralized AC-coupled HPSs.
ii. Distributed AC-coupled HPSs.

\subsubsection{DC-Coupled Hybrid Power Systems}

In DC-coupled HPSs configuration, all the ECSs, unlike AC-coupled HPSs, are connected to a DC main bus before being connected to the load. Connection with the AC loads is done through a main inverter.

\section{PROPOSED SYSTEMS}

\subsection{Proposal 1}

Fig.(4) shows the wind turbine and Generator set are directly connected to the AC bus and thus there are no losses associated with the directly consumed part of the power from these energy sources. However, the power from the PV-arrays face the DC/AC power converter before it is connected to the AC-bus. Thus, losses associated with this converter are considered even for the directly consumed part of the power from the PV-arrays. For the part of the power consumed from the battery, losses associated with the AC/DC converter, the battery, and DC/AC are also taken into account over and above the losses considered with the direct power consumption cases.

The (Table 1) gives a summary of equations for the efficiency of power consumption from the different energy sources whether the power is used directly or indirectly for proposal-1.

\subsection{Proposals 2}

If some part of the PV-array power is to be used from the battery after the energy has been stored, then Proposal 2 give the same and higher efficiency of utilization than Proposal 1 provided that no more than $85 \%$ of the PV-array power is used directly. Figure (5) shows the second suggested proposal. 
The (Table 2) gives a summary of equations for the efficiency of power consumption from the different energy sources whether the power is used directly or indirectly for proposal-2.

\subsection{Efficiency comparisons of the suggested system}

It can be observed from the last figures that the power losses with the direct power consumption from the PV-arrays depend on DC/AC converter with proposal-1 and (Charge controller + Inverting device) with proposal 2. For the consumption of PV-power from the battery, the losses across the DC/DC converter, AC/DC converter, battery charging and DC/AC converter contribute for the consumption efficiency with proposal-1. Similarly, losses associated with charge controller, battery charging and inverting device contribute for the power loss with proposal-2.

\section{POWER MODELING AND SIMULATION}

Different types of power management methods are defined. For each method, mathematical modeling is designed based on the power balance (between the supply side and the load side), the battery bank charging/discharging limits (upper and lower energy limits) and the sizing of system elements. Then, MATLAB/Simulink models are designed for the mathematical models of each and every method. The simulation models, which are designed for each method, are then simulated.

\subsection{Simplified Electrical Circuit Model}

For the simple model (Figure 7), mathematical modeling is performed based on power or current control mechanism to check the balance of the instantaneous power or current between the supply side and the load side at the main DC-bus. The power balancing plays a big role in the control system of the hybrid power systems ${ }^{(19)}$.

Applying power balancing at the DC-bus, we have the fundamental mathematical model expressed as:

$$
P_{\text {load }}(t)=p_{w g}(t)+P_{d g}(t)+P_{p v}(t)+P_{b b}(t)
$$

Where,

$p_{w g}(t)$ the injected power into the DC-bus from the wind generator.

$P_{d g}(t)$ the injected power from the diesel generator into the DC-bus.

$P_{p v}(t)$ the injected power from the PV-array into the DC-bus. 
$P_{b b}(t)$ the injected power from the battery bank into the DC-bus the energy measured at the DC-bus.

The current equation is as follows:

$i_{\text {load }}(t)=i_{w g}(t)+i_{d g}(t)+i_{p v}(t)+i_{b b}(t)$

The maximum power capacities of the PV-arrays and Wind turbines are, then, determined by multiplying the number of PV-panels and Wind turbines with the corresponding Watt-peak capacities of a selected PV-panel and Wind turbine respectively.

The maximum power sharing of each system elements within the cycle which contributes to the sizing of system elements can be represented in Figure (8) .

\subsection{Matlab/Simulink Modeling of the Proposed Hybrid System}

The Matlab/Simulink simulation model of the proposed system based on the previous equations is as shown below:

The load demand data (hourly average power demand) is one of the inputs. In Figure 8, it can be seen that these input data are transformed into the DC-bus where the different proposed systems are applied. Over and above, the calculated powers from a PV-panel and a wind turbine which are evaluated from the solar insulation and wind speed data respectively.

The detailed modeling of the battery bank is simulated by simple Simulink which can be referred when dealing about each power system is shown by Figure (10). ${ }^{(19,20)}$

The detail of the "Charging/Discharging Control" subsystem of the battery bank which is shown in Figure (10) .

\section{SIMULATION RESULTS OF THE PROPOSED HYBRID SYSTEM}

\subsection{Simulation Results of the battery bank}

The simulation results for the power shares among the energy sources and the energy stored in the battery bank is shown by Figure (12).

The power losses associated with the charging/discharging of the battery bank and power electronic devices are indicated on Figure (13).

\subsection{Simulation Results of the Generation set:}

Based on the mathematical modeling equations and the Simulink model for the Generation set is designed and is given by Figure (14) . 
Taking the "Generation set control" techniques, which are discussed in the mathematical modeling, into account, the detail of the "Generation set Control" is shown in Figure (15).

Simulation of the model for Generation set given by Figure (14) gives results for the power shares and stored energy show in (Figure 16) ${ }^{(20)}$.

As it can be referred to Figure (16), the Generation sets are supplying exactly the load demand at each and every time for their controls. The battery banks show neither charging nor discharging statuses, and this is indicated by the constant energy (initial battery energies).

\subsection{MATLAB/Simulink Modeling of PV arrays}

The Simulink model of PV-arrays in Figure (9) can be modified for Only PV-arrays with battery bank by removing all Simulink blocks which are not interrelated to the PVarrays with battery bank.

\subsection{MATLAB/Simulink Modeling for Wind turbines}

The Simulink model of Wind turbines in Figure (9) can be modified for Only wind turbines with battery bank by removing all Simulink blocks which are not related to the wind turbines with battery bank. ${ }^{(21)}$

\subsection{MATLAB/Simulink Modeling for the Renewable Power System}

The Simulink model (Figure 19) accepts three basic inputs. These include data inputs from the load demand, the solar power (from solar irradiation) and the wind turbine power (from speed). The power conversion losses associated with the battery bank, DC/DC converters and AC/DC converters are also included.

The simulation results are shown in Figure(20). The instantaneous power shares of system elements and the energy levels of the batteries are shown for the load.

\section{CONCLUSIONS}

A hybrid power system which consists of diesel generation set, PV-arrays and wind turbines with energy storing devices (battery bank) and power electronic devices has been discussed in this paper to achieve an efficient and system configuration so that hybrid power sources could improve the life of people especially in rural areas of IRAQ where electricity from the main grid has not reached yet. For the different energy sources, where some are AC sources and others DC sources, different connecting diagrams are proposed in this work. The 


\section{DESIGN AND SIMULATION OF HYBRID SYSTEM FOR ELECTRICITY GENERATION IN IRAQI RURAL REGIONS}

proposed connecting configurations are compared to select the one with the best efficiency of power consumption to the consumers by considering each power sources independently. It is found that with the Mixed-coupling Hybrid systems, best efficiency of power consumption can be achieved when compared with the other diagrams and the selected diagram is used for further investigation.

With typical AC-load simulation, solar irradiation and wind speed readings of a typical site, the sizing approaches of each energy sources, the battery bank and power electronic devices are discussed in this paper. Having described the preliminary sizing approaches of system elements for the selected diagram, different power management techniques are defined based on the typical load demand curves, where the diesel Generation st gets supports from the renewable energy sources and the battery bank. The different systems which resulted from the defined power management strategies are modeled using MATLAB/Simulink blocks.

The simulation results (power shares, losses and energy level of the battery bank) verify that the results are in accordance to the mathematical modeling which depends on the governing energy and power equations. The demand is met at every time and the charging/discharging of the battery is controlled between the upper and lower limits.

\section{REFERENCES}

1. N. Phuangpornpitak and S. Kumar, "PV hybrid systems for rural electrification in Thiland," Renewable and Sustainable Energy Reviews, ScienceDirect, vol. 11, Iss. 7, pp. 1530-1543, September 2007.

2. ARE - shining a Light for a progress, "Hybrid power systems based on renewable energies- A suitable and cost-competitive solution for rural electrification," www.ruralelec.org/fileadmin/DATA/Documents/06_Publications/Position_papers/AR E-WG_Technological_Solutions_-_Brochure_Hybrid_Systems.pdf, Ed.: AREAlliance for Rural Electrification, 2008.

3. O.C. Onar, M. Uzunoglu, and M.S. Alam, "Dynamic modeling, design and simulation of a wind/fuel cell/ultra-capacitor-based hybrid power generation system," Journal of Power Sources- ScienceDirect, vol. 4, pp. 707-722, 28th March 2006.

4. Ahmed Agus Setiawan, Yu Zhao, Rob Susanto-Lee, and Chem. V. Nayar, "Design, economic analysis and environmental considerations of mini-grid hybrid power 
system with reverse Osmosis desalination plant for remote areas," Renewable EnergyElsevier, vol. 34, Iss.2, pp. 374-383, February 2009.

5. J. F. Baalbergen, "System design and power management of a generator-set with energy storage for a 4Q drive," in Electrical Power Engineering, MSc: Delft University of Technology, October 2007.

6. J. Leuchter, P. Bauer, O. Kurka, and V. Hájek, "Efficiency Investigation of Mobile Power Sources with VSCF Technology," in International Symposium on Power Electronics, Electrical Drives, Automation and Motion, SPEEDAM 2006, Taormina, 05 July 2006, pp. 475 - 480, ISBN: 1-4244-0193-3.

7. J. Leuchter, P. Bauer, and V. Stekly, "System Variation of Electrical GEN-SET with Energy Buffer," in Power Conversion Conference - Nagoya, 2007. PCC '07, 18 June 2007, pp. 1401-1408, ISBN:1-4244-0844-X.

8. N. Rapapate and Ö. Göl, "Use of photovoltaic systems for rural electrification in Thailand," http://www.icrepq.com/icrepq07/352-Rapapate.pdf.

9. Miro Zeman, " Introduction to solar electricity," in SOLAR CELLS, TU Delft, pp. 1.1- 1.13 .

10. Mukund R. Patel, "Wind and Solar Power Systems". Kings Point, New York: CRC Press LLC, 1999, ISBN:0-8493-1605-7.

11. IEEE, "IEEE Guide for Array and Battery Sizing in Stand-Alone Photovoltaic (PV) Systems." vol. IEEE Std 1562 ${ }^{\mathrm{TM}}-2007$ New York, USA, 12 May 2008.

12. T.L. Skvarenina, "The Power Electronics handbook": CRC Press LLC, 2000 Corporate Blvd.NW, 2002, ISBN: 0-8493-7336-0.

13. Hussein Ibrahimab, Adrian Ilincaa, and Jean Perronb, "Comparison and Analysis of Different Energy Storage Techniques Based on their Performance Index," in IEEE Electrical Power Conference Canada, 2007, pp. 393 - 398.

14. E. Muljadi and J. T. Bialasiewicz, "Hybrid Power System with a Controlled Energy Storage," in 29th Annual Conference of the IEEE Industrial Electronics Society (IEEE Cat No 03CH37468) IECON-03. vol. 2 Roanoke, Virginia, 2-6 November 2003, pp. 1296 - 1301, ISBN: 0-7803-7906-3

15. Justin R. Farmer, "A comparison of power harvesting techniques and related energy storage issues," in Mechanical Engineering. vol. Master of Science Blacksburg, Virginia: Virginia Polytechnic Institute and State University, 15 May 2007, p. 115.

16. D. Linden and T. B. Reddy, "Handbook of batteries", 3rd ed. New York: McGraw Hill Education, 2002, ISBN: 978-0-07-135978-8. 
17. BatteryUniversity.com, "Energy density and Power density, http://www.batteryuniversity.com/partone-5A.htm," Since 2003.

18. BAE SECURA PVV CELL Solar, "Technical Specification for Valve Regulated Lead-Acid Batteries (VRLA), www.bae-berlin.de," BAE Batterien GmbH, Ed. Berlin, August 2008.

19. IEEE, "IEEE Recommended Practice for Sizing Lead-Acid Batteries for Photovoltaic (PV) Systems." vol. IEEE Std 1013-2000 3 Park Avenue, New York, NY 100165997, USA, 30 March 2000.

20. Electropaedia, "Battery and Energy Technologies - Performance Characteristics by Ragone Plots," http://www.mpoweruk.com/performance.htm .

21. S.J. Park, B.B. Kang, J.P. Yoon, I.S. Cha, and J.Y. Lim, "A Study on the Stand-Alone Operating or Photovoltaic-Wind Power Hybrid Generation System," in 35th Annual IEEE Power Electronics Specialists Conference, Aachen, Germany, 20-25 June 2004, pp. $2095-2099$.

Table (1): Equations for calculating the efficiency of powers from the different sources for proposal -1.

\begin{tabular}{|l|l|l|l|}
\hline Power source & Directly, $\eta_{\text {directly }}$ & Via battery, $\eta_{\text {via_battery }}$ & Total, $\eta_{\text {tot }}$ \\
\hline PV-array, $P_{p v}$ & $\eta_{d} \eta_{d a}$ & $\left(1-\eta_{d}\right) \eta_{d a} \eta_{a d} \eta_{b} \eta_{d a}$ & $\eta_{d} \eta_{d a}+\left(1-\eta_{d}\right) \eta_{d a}^{2} \eta_{a d} \eta_{b}$ \\
\hline Wind turbine, $P_{w g}$ & $\eta_{d}$ & $\left(1-\eta_{d}\right) \eta_{a d} \eta_{b} \eta_{d a}$ & $\eta_{d}+\left(1-\eta_{d}\right) \eta_{a d} \eta_{b} \eta_{d a}$ \\
\hline Genset, $P_{d g}$ & $\eta_{d}$ & $\left(1-\eta_{d}\right) \eta_{a d} \eta_{b} \eta_{d a}$ & $\eta_{d}+\left(1-\eta_{d}\right) \eta_{a d} \eta_{b} \eta_{d a}$ \\
\hline
\end{tabular}

Table (2): Equations for calculating the efficiency of powers from the different sources for proposal -2.

\begin{tabular}{|l|l|l|l|}
\hline Power source & Directly, $\eta_{\text {directly }}$ & Via battery, $\eta_{\text {via_battery }}$ & Total, $\eta_{\text {tot }}$ \\
\hline PV-array, $P_{p v}$ & $\eta_{d} \eta_{c c} \eta_{d a}$ & $\left(1-\eta_{d}\right) \eta_{c c} \eta_{b} \eta_{d a}$ & $\eta_{d} \eta_{c c} \eta_{d a}+\left(1-\eta_{d}\right) \eta_{c c} \eta_{b} \eta_{d a}$ \\
\hline Wind turbine, $P_{w g}$ & $\eta_{d}$ & $\left(1-\eta_{d}\right) \eta_{a d} \eta_{b} \eta_{d a}$ & $\eta_{d}+\left(1-\eta_{d}\right) \eta_{a d} \eta_{b} \eta_{d a}$ \\
\hline Genset, $P_{d g}$ & $\eta_{d}$ & $\left(1-\eta_{d}\right) \eta_{a d} \eta_{b} \eta_{d a}$ & $\eta_{d}+\left(1-\eta_{d}\right) \eta_{a d} \eta_{b} \eta_{d a}$ \\
\hline
\end{tabular}




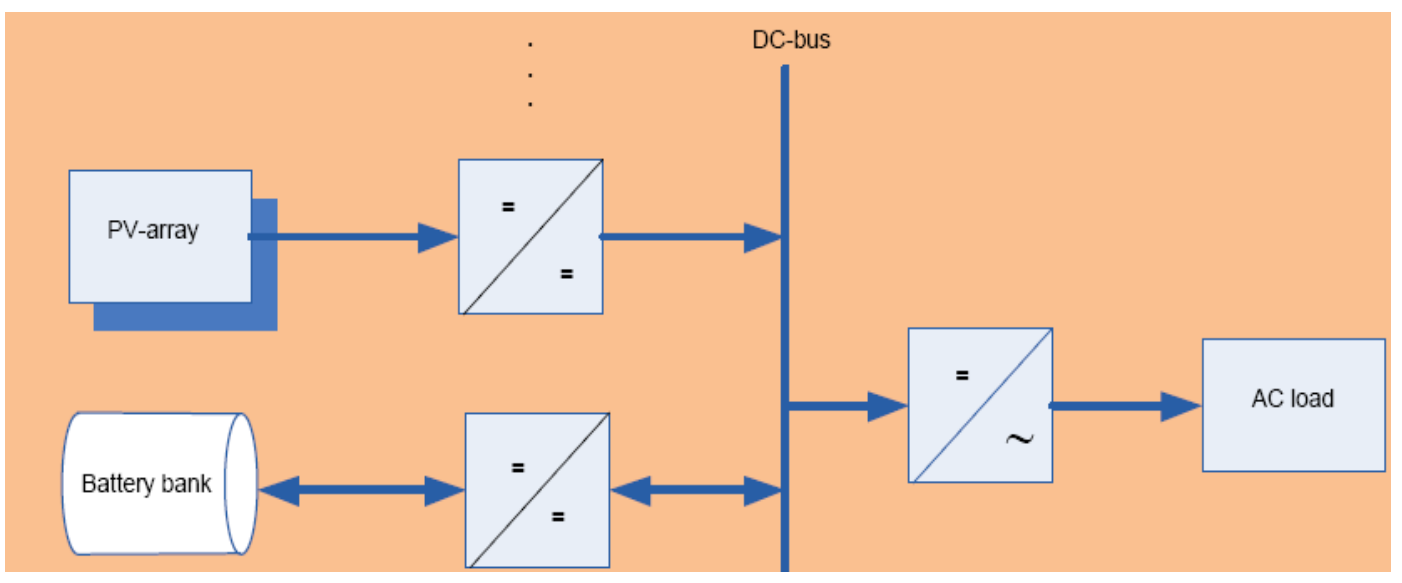

Fig.(1): PV-system supplying AC loads connected at the main DC-bus.

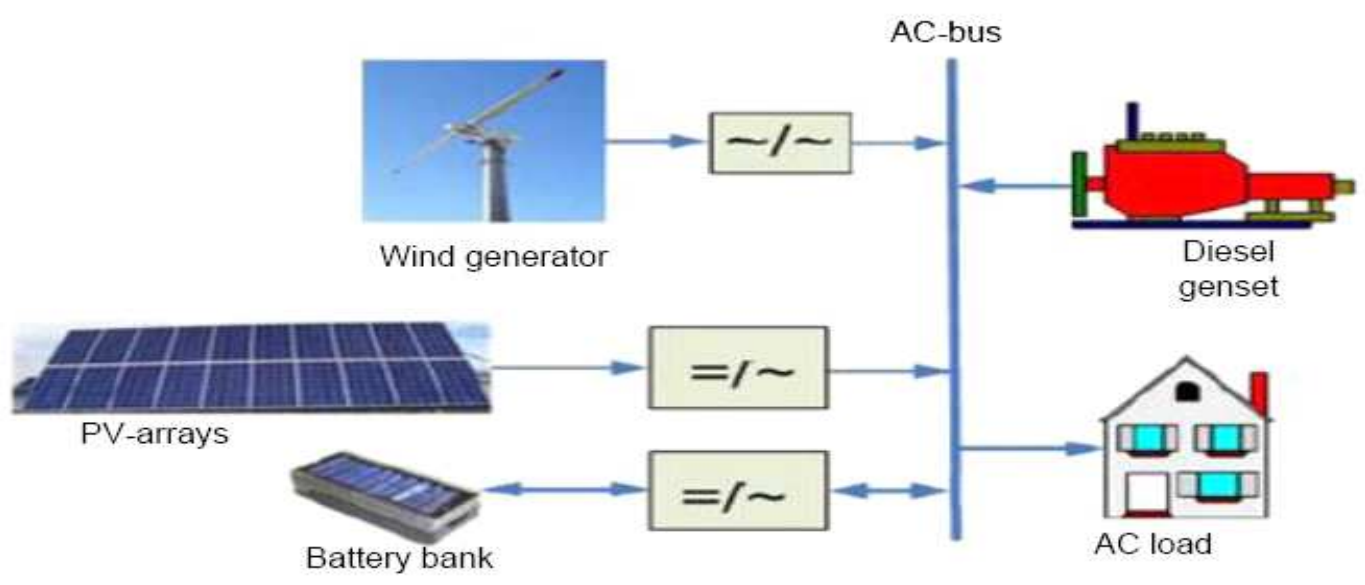

Fig.(2): Centralized AC-coupled HPSs.

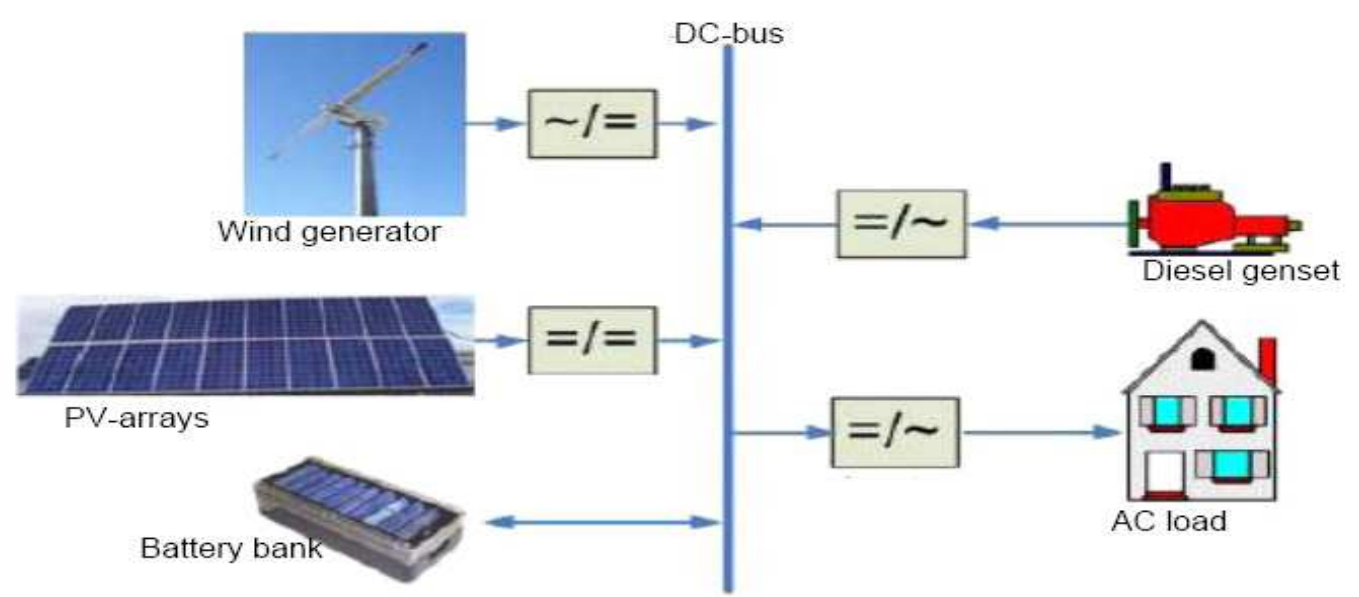

Fig.(3): DC-Coupled HPSs. 


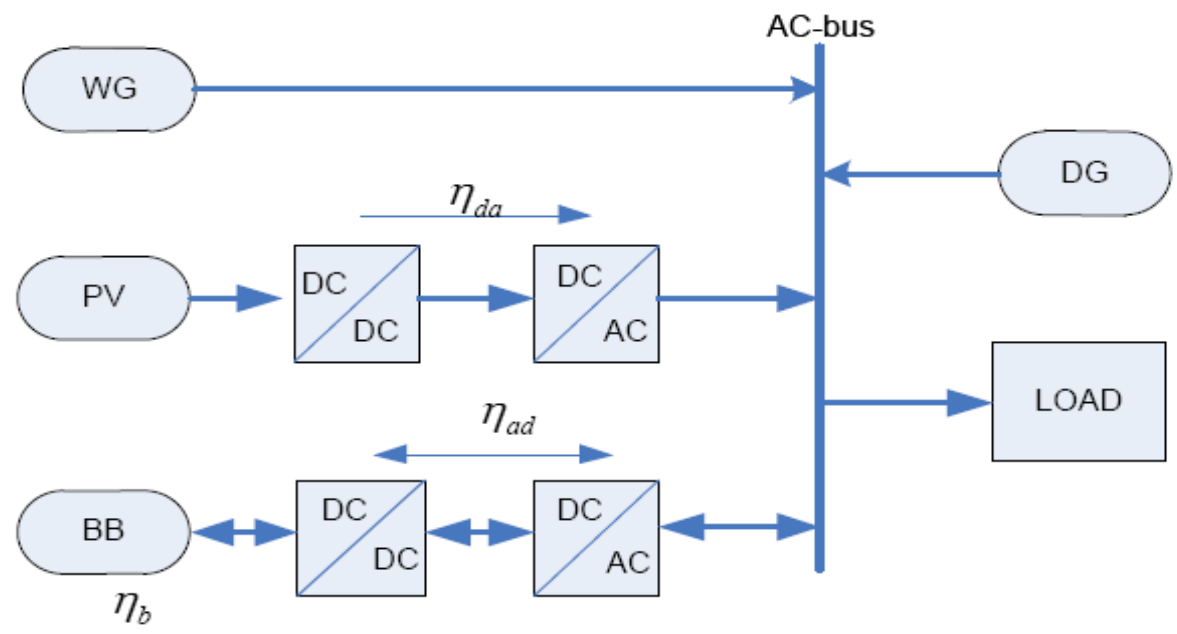

Fig.(4): the first suggested hybrid system.

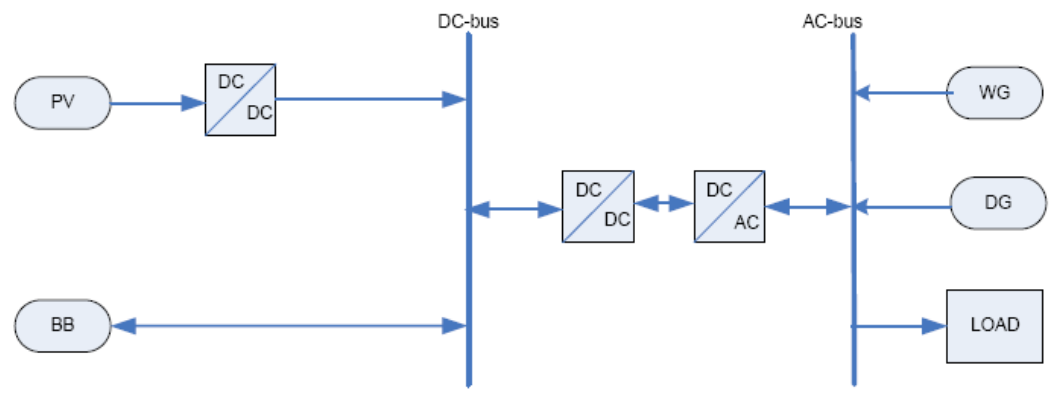

Fig.(5): The second suggested Hybrid System.

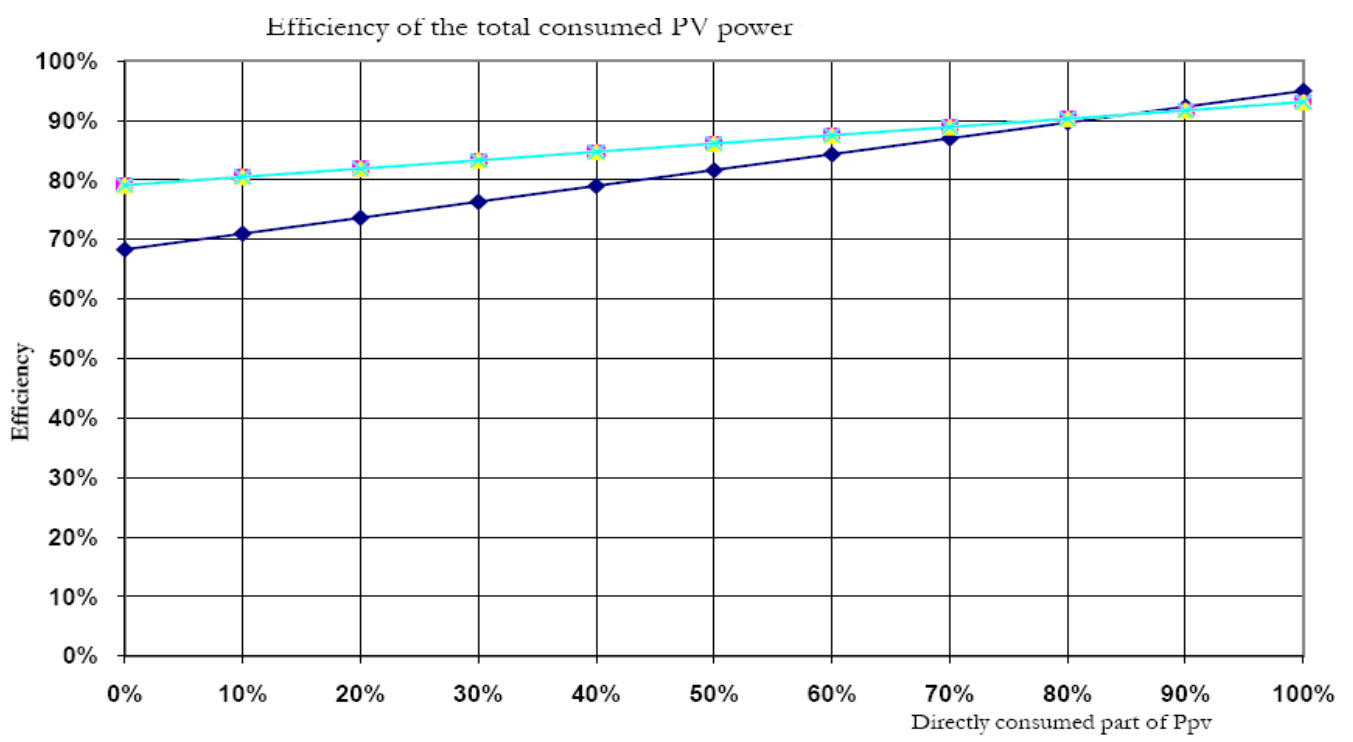

Fig.(6):Comparison of efficiency for proposals 1 and 2. 


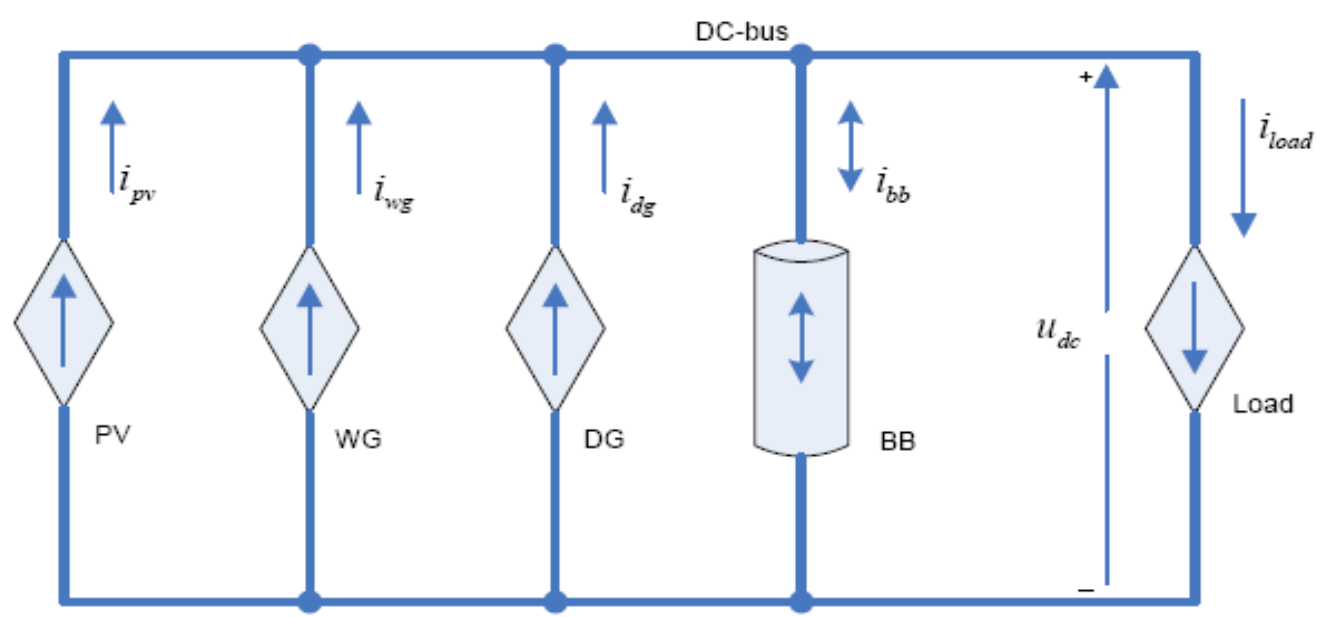

Fig.(7): Simplified Electrical Model for the Hybrid System.

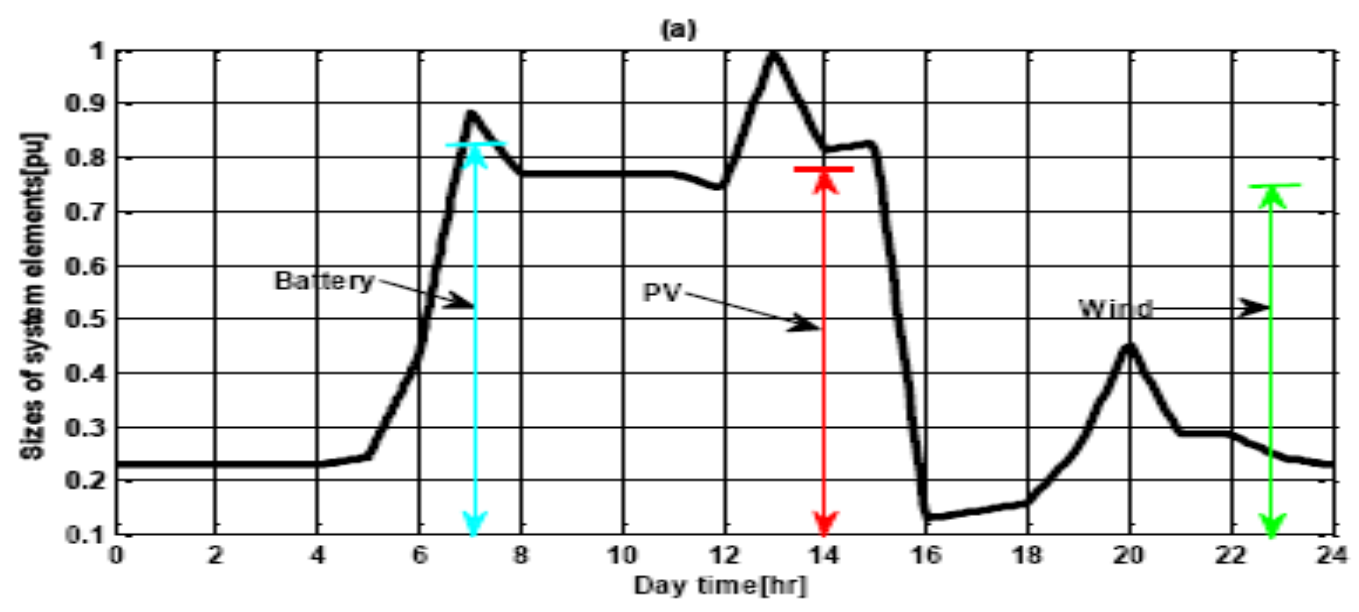

Fig. (8): The max power sharing of each system elements.

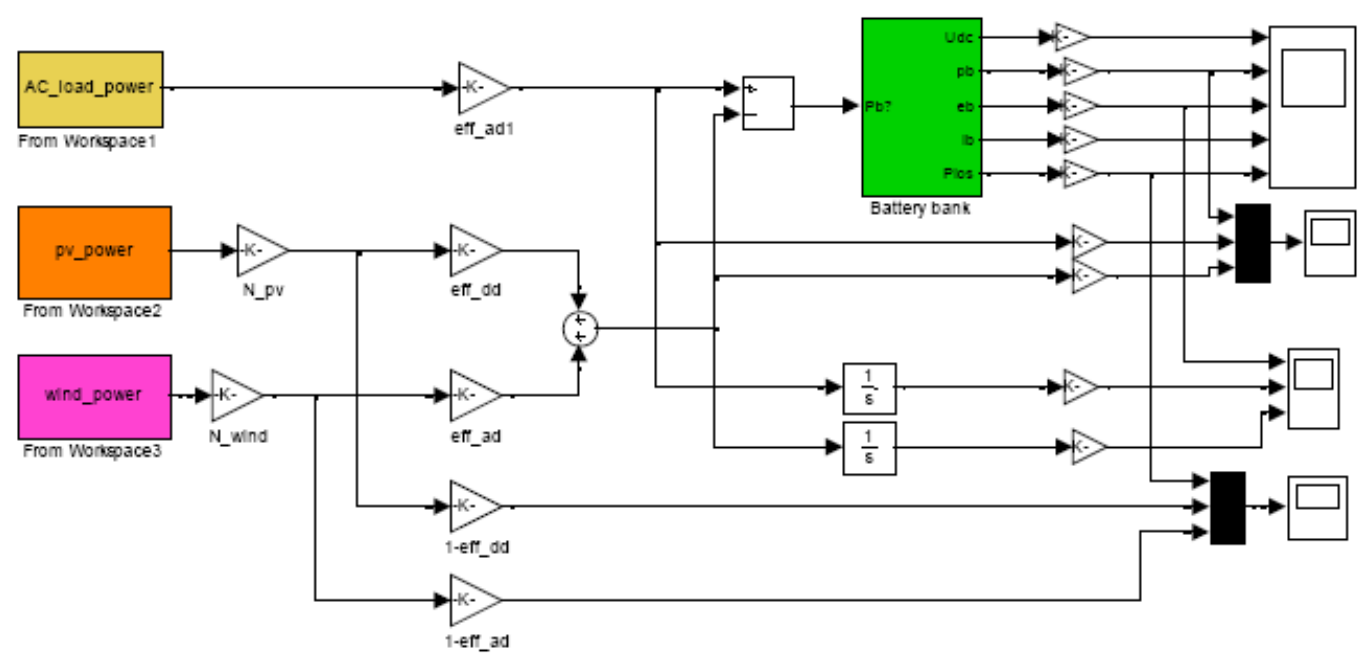

Fig.(9): Matlab/Simulink model of the proposed hybrid system. 


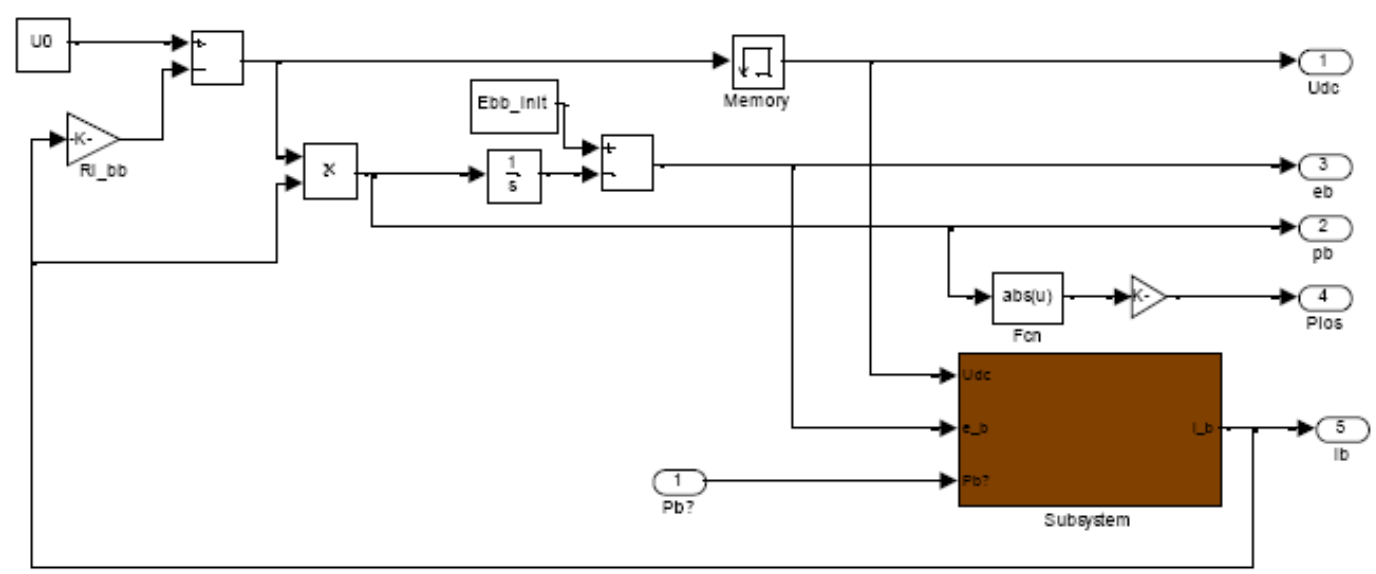

Fig.(10): Simulink modeling of rechargeable lead acid battery.

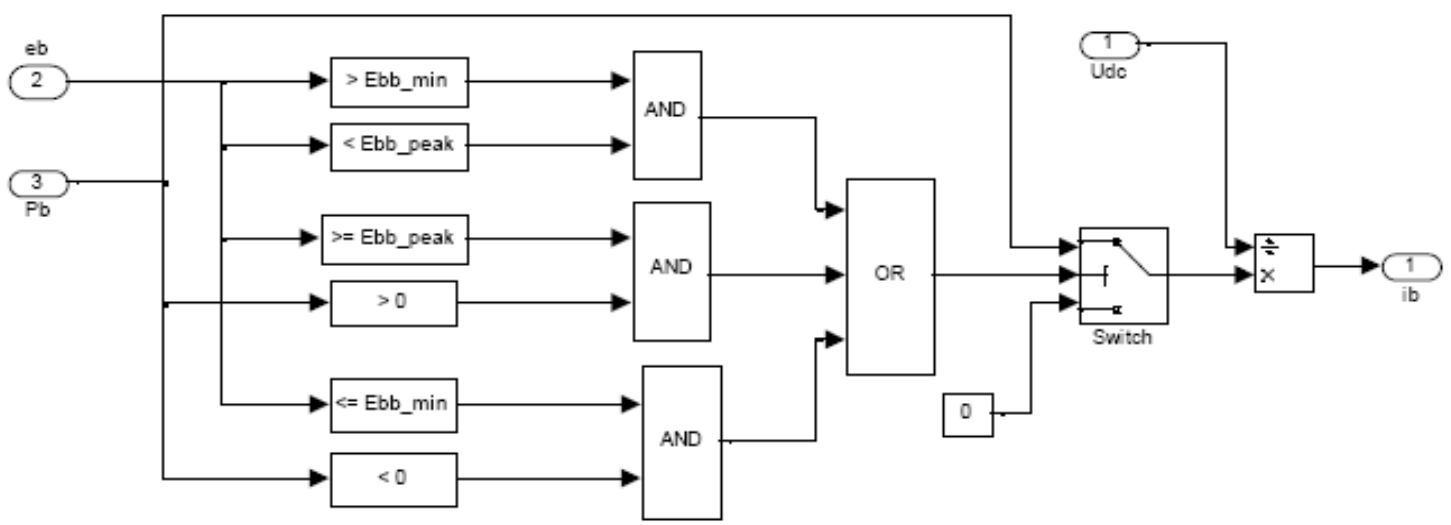

Fig.(11): Detail of the "Charging/Discharging Control" of the battery bank.

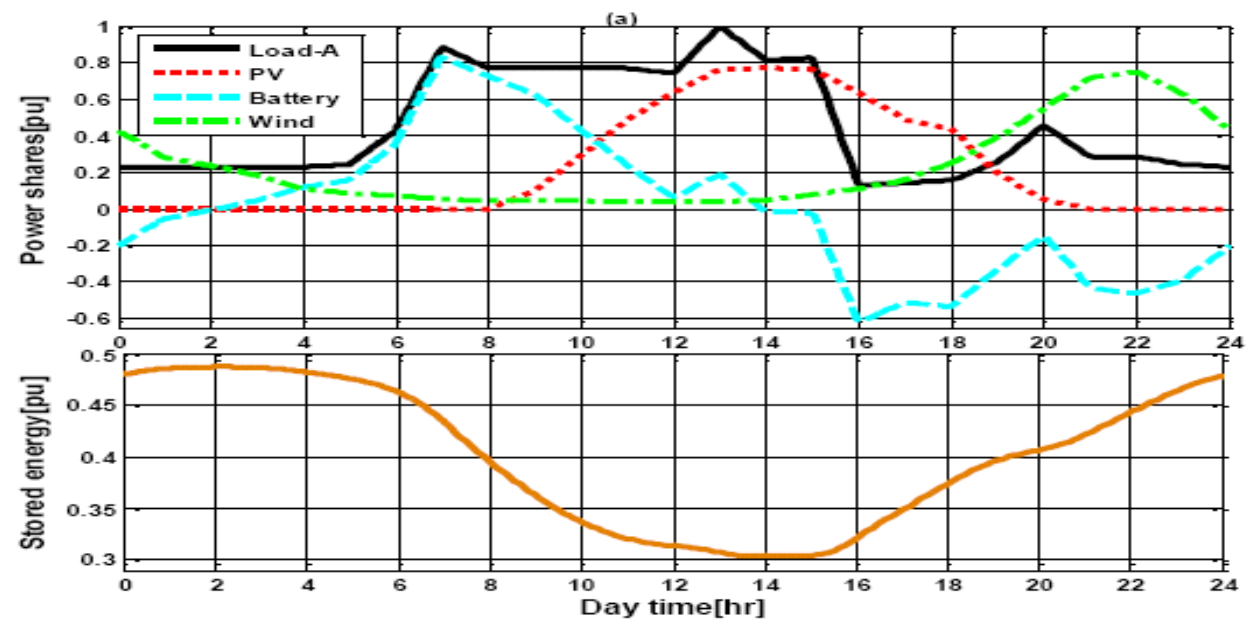

Fig.(12): Simulation results of the power proposed system for the power shares and stored energy in the battery bank. 


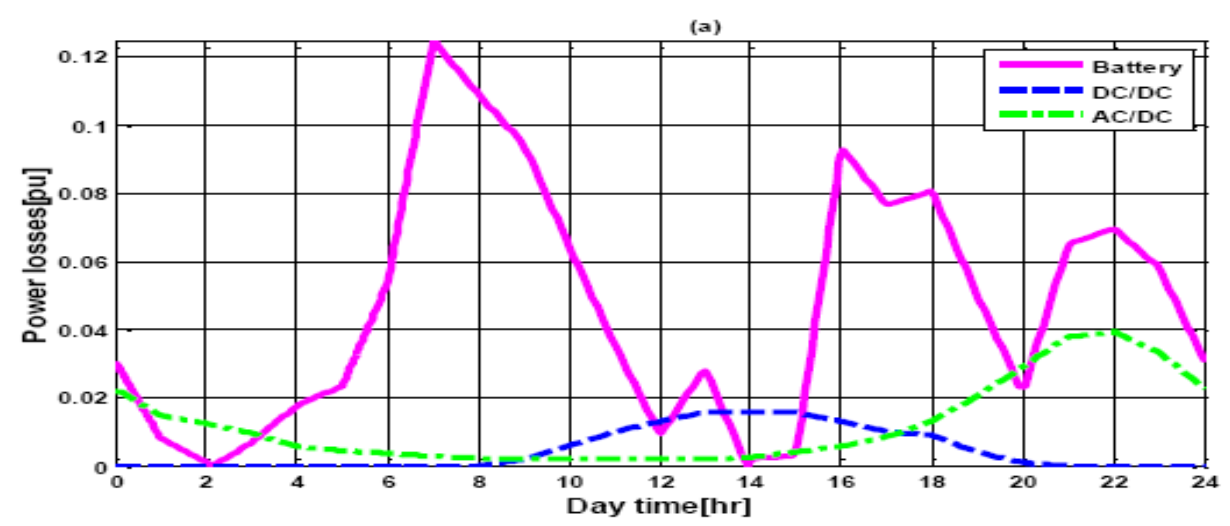

Fig.(13): Power losses associated with the battery bank, DC/DC and AC/DC converters for the proposed hybrid system.

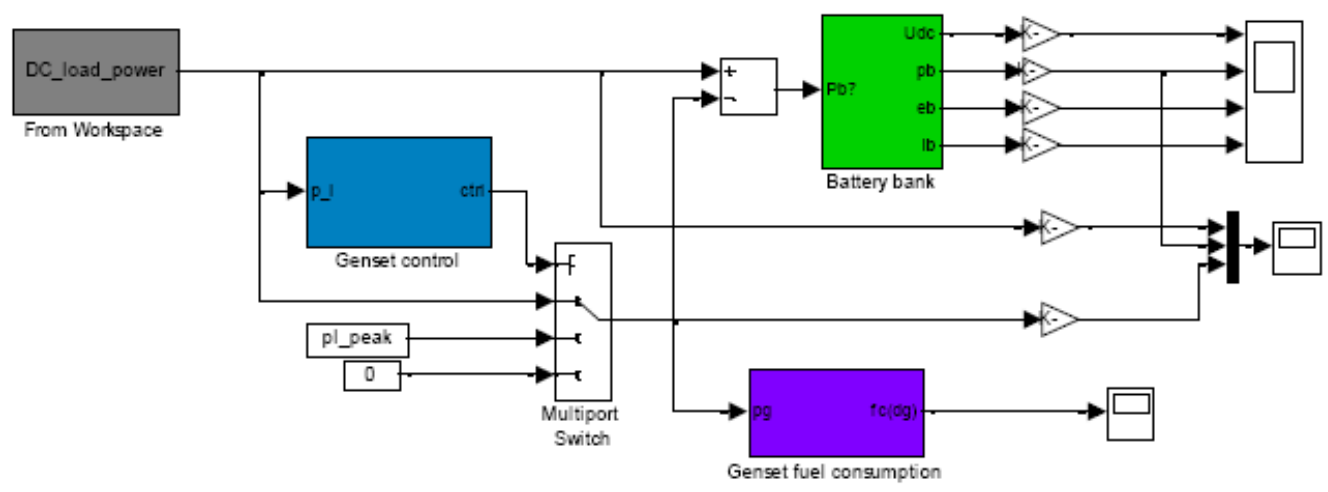

Fig.(14): MATLAB/Simulink model for simulation of Only Generation set.

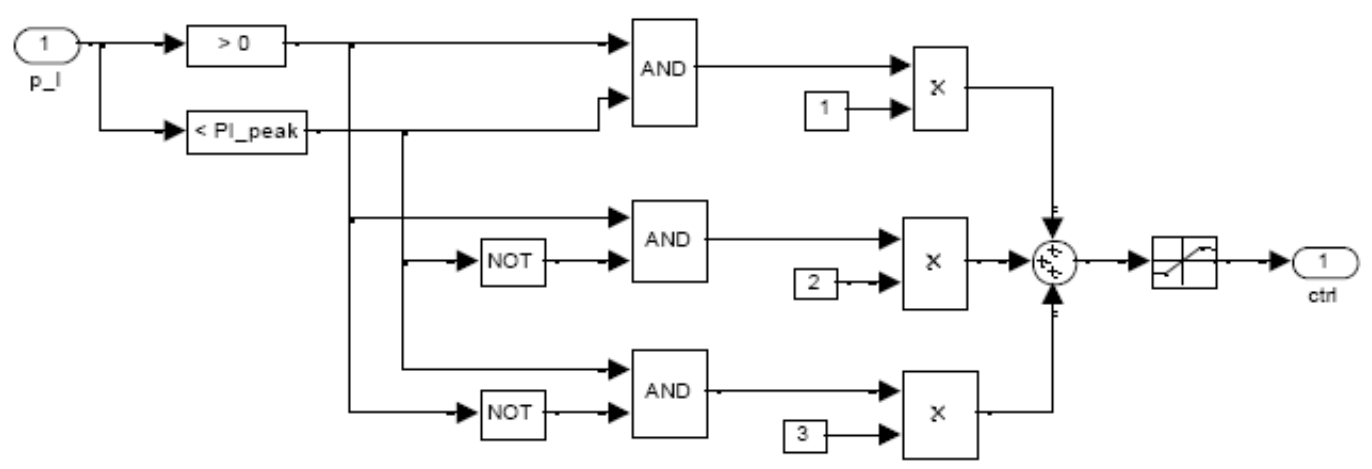

Fig.(15): Detailed MATLAB/Simulink model of the "Generation set control" sub-system for Generation set. 


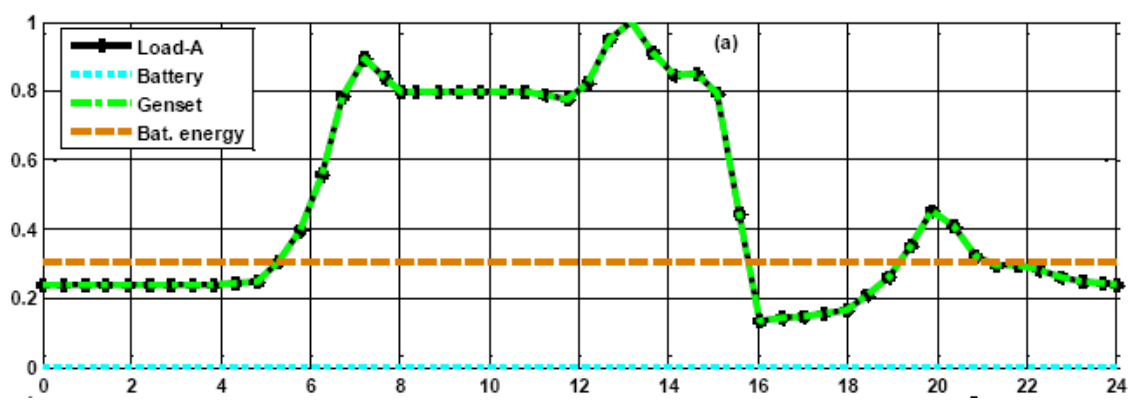

Day time (hour)

Fig.(16): Simulation results of the Generation set for the power shares and stored energy in the battery bank.

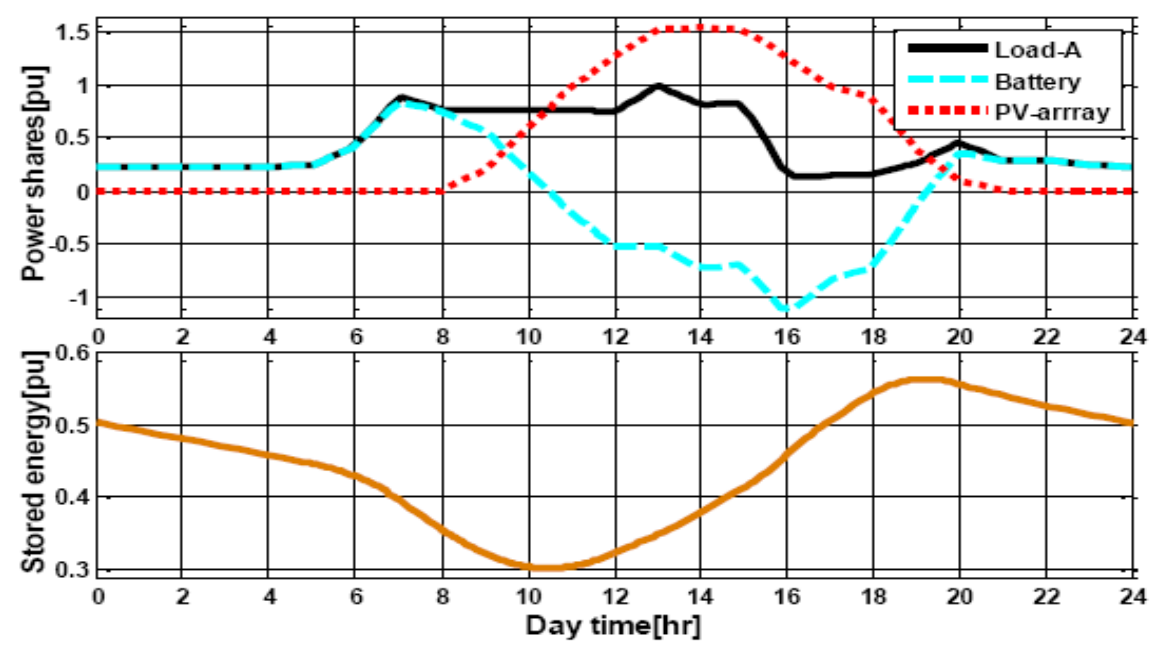

Fig.(17): Simulation results of the PV-arrays for the power shares and stored energy in the battery bank.

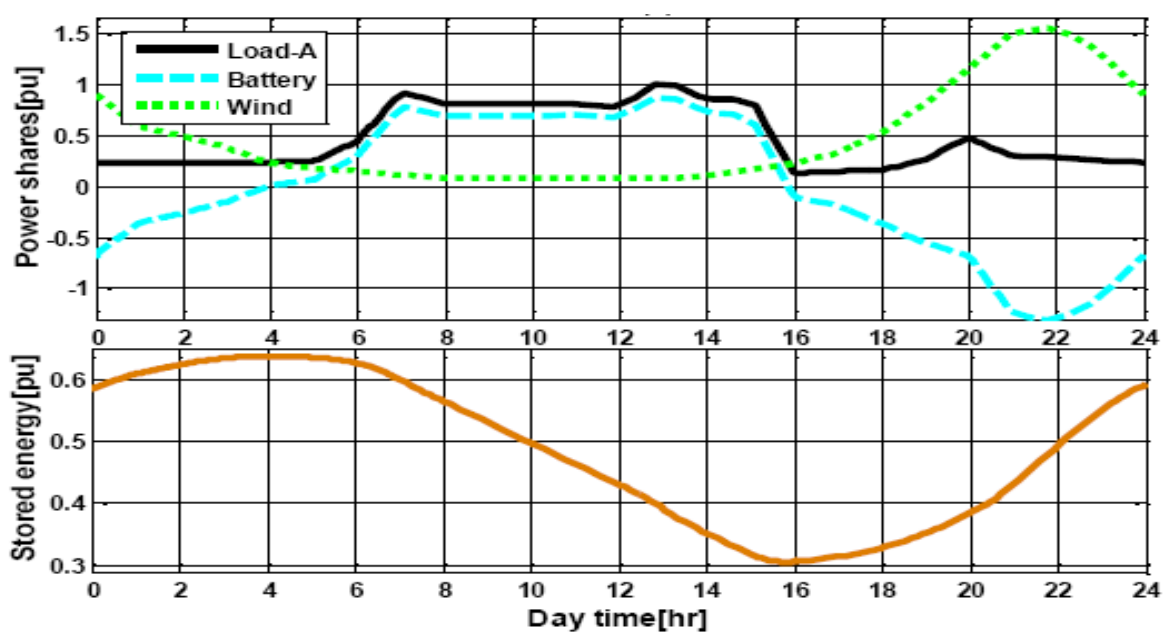

Fig.(18): Simulation results of the Wind turbines for the power shares and stored energy in the battery bank. 


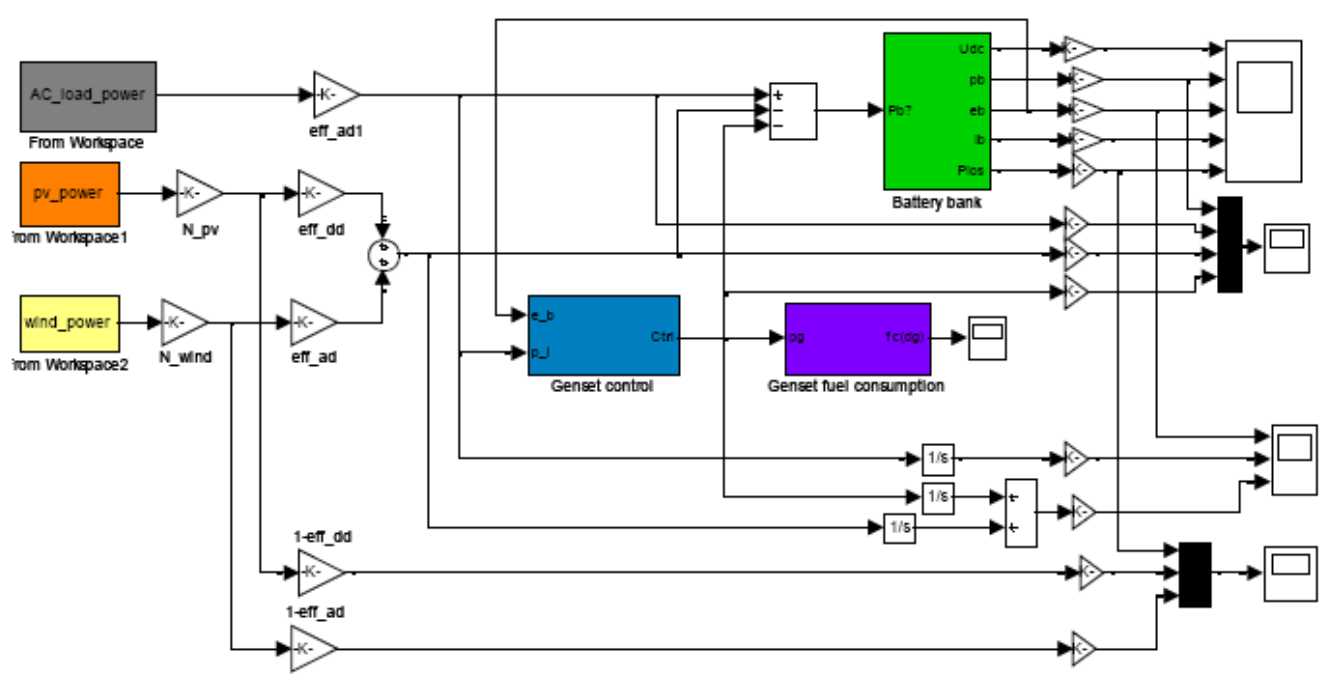

Fig.(19): MATLAB/Simulink model of Renewable Power System.
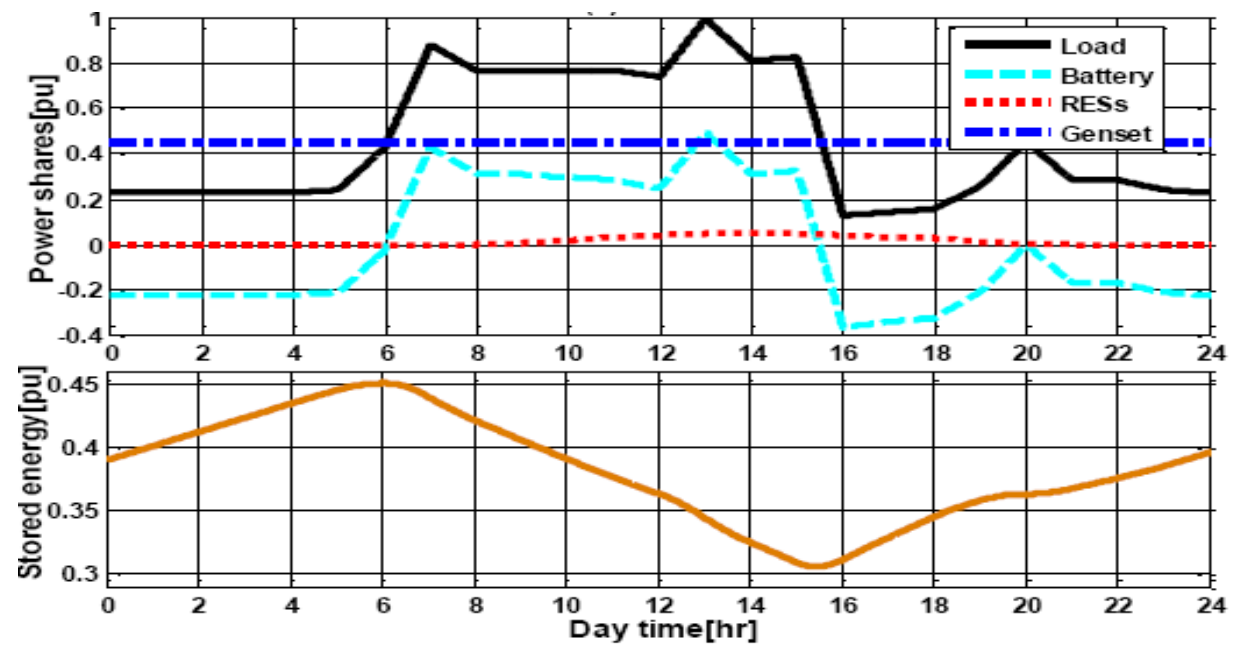

Fig.(20): Simulation results of the renewable system for the power shares and stored energy in the battery bank. 


\section{تصميم ومحاكاة منظومة هجينة لتوليد الطاقة الكهريائية في المناطق الريفية في العرق}

$$
\text { كريم كاظم جاسم }
$$

كلية الهندسة - جامعة ديالى

$$
\text { مركز بحوث الطاقة والوقود- الجامعة }
$$$$
\text { مركز بحوث الطاقة والوقود- الجامعة }
$$$$
\text { التكنولوجية }
$$

الخلاصة:

في هذا البحث تم التطرق إلى تصميم ومحاكاة منظومة منكاملة (شمسية-رياح-ديزل) ملائمة للعمل في المناطق

$$
\text { الريفية والبعيدة عن الثبكة الكهربائية لنزويد المواطنين بالطاقة الكهربائية. }
$$

وفى النماذج المقترحة تم مراعاة الأداء الجيد والكفاءة العالية للمنظومة بالنسبة لاستهلاكك الطاقة والتركيز على المثالية

والجدوى الاقتصادية من نشر هذه المنظومات في مناطق القطر المختلفة مثل الاهوار والمناطق الصحراوية والريفية لتقليل

الضغط على الثبكة الكهربائية العامة.

الكلمات الدالة: الخلايا الثمسية، نوليد طاقة كهربائية، الطاقات المتجدية العادة. 